\title{
Promoting an Academic International Profile in Undergraduate Students of Psychology Programs in Colombia ${ }^{1}$
}

Promoviendo un PerfilAacadémico Internacional en Estudiantes de Licenciatura en Psicología en Colombia.

\section{Germán Andrés Torres-Escobar and Rolan Arcadio Correa-Lopez ${ }^{2}$}

Universidad Católica Luis Amigó, Colombia

\footnotetext{
${ }^{1}$ Received: December 10th 2019 /Accepted: September 15th 2020

2 german.torreses@amigo.edu.co; rolan.correalo@amigo.edu.co
} 


\section{Abstract}

The present reflective article aims to describe some challenges that psychology programs in Colombia must face in the future, in order to let their students achieve an international professional profile and to improve their academic quality. First of all, psychology programs need to implement a bilingual curriculum, with many basic and professional courses in a foreign language like English, to teach students to think social and psychological problems in a wide intercultural way (Coulson \& Homewood, 2016; Taylor \& Hulme, 2015). Secondly, psychology professors should motivate their students to acquire higher levels of engagement with bilingual communication learning, to have better opportunities of professional development by applying to academic exchange experiences with international universities.

Keywords: Psychology programs; International profile; Bilingual education; Academic exchange; English Proficiency.

\section{Resumen}

El presente artículo reflexivo tiene como objetivo describir algunos desafíos que los programas de psicología en Colombia deben enfrentar en el futuro, a fin de permitir que sus estudiantes alcancen un perfil profesional internacional y mejorar su calidad académica. En primer lugar, los programas de psicología necesitan implementar un plan de estudios bilingüe, con muchos cursos básicos y profesionales en un idioma extranjero como el inglés, para enseñar a los estudiantes a pensar en problemas sociales y psicológicos de una manera intercultural amplia (Coulson y Homewood, 2016; Taylor y Hulme, 2015). En segundo lugar, los profesores de psicología deberían motivar a sus estudiantes a adquirir niveles más altos de compromiso con el aprendizaje de la comunicación bilingüe, para tener mejores oportunidades de desarrollo profesional mediante la aplicación de experiencias de intercambio académico con universidades internacionales.

Palabras clave: Programas de psicología; Perfil internacional;, Educación bilingüe; Intercambio académico; Dominio del inglés. 


\section{Resumo}

O presente artigo reflexivo tem como objetivo descrever alguns desafios que os programas de psicologia na Colômbia devem enfrentar no futuro, com a finalidade de permitir que seus estudantes alcancem um perfil profissional internacional e melhorar sua qualidade acadêmica. Em primeiro lugar, os programas de psicologia precisam implementar um plano de estudos bilíngue, com muitos cursos básicos e profissionais em um idioma estrangeiro como o inglês, para ensinar os estudantes a pensar em problemas sociais e psicológicos de uma forma intercultural ampla (Coulson e Homewood, 2016; Taylor e Hulme, 2015). Em segundo lugar, os professores de psicologia deveriam motivar seus estudantes para adquirir níveis mais altos de compromisso com a aprendizagem da comunicação bilíngue, para ter melhores oportunidades de desenvolvimento profissional por meio da aplicação de experiências de intercâmbio acadêmico com universidades internacionais.

Palavras chave: Programas de psicologia; Perfil internacional; Educação bilíngue;

Intercambio acadêmico; Domínio do inglês. 


\section{Introduction}

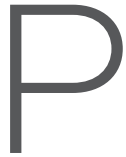

sychology programs in Colombia, are regulated by legal Resolution 3461 of 2003 (Ministerio de Educación Nacional de Colombia, 2003), which states, the basic academic contents of basic and professional courses across the curriculum. This law mentions article 2 , every program should teach a second language as part of its curriculum structure, but it doesn't clarify the academic purpose of learning a foreign language nor the impact on career development of students.

Many psychology programs have currently a list of English courses that are articulated by the level of skills and prepare students to achieve basic levels of competence in daily life situations according to an intermediate or B level of the Common European Framework of Reference. Other universities are more demanding and also request their students to present international exams like the Test of English as a Foreign language TOEFL (Ahern \& Litt, 2018; Mustafa \& Anwar, 2018) or the International English Language Testing System IELTS (Sabet \& Reza, 2017; Nosrati, 2015) as a condition to get their professional certificate.

However, teaching English as a content area is not articulated with disciplinary or professional contents of universities' careers. In many cases, it's been seen as isolated from the curricula, because it's considered as a complementary educational field. The current version of Saber-Pro[1] exams (Instituto Colombiano para la Evaluación de la Educación, 2018) confirms the idea because it assesses under degree student's general competences in five fields of knowledge which are: Critical Reading, Quantitative Reasoning, Citizen Competences, Writing Communication and English. The English Module of Saber-Pro exams specifically intends to evaluate basic concepts of English and classify students' level of skill in levels A (basic) and B (intermediate).

The difficulty with teaching a second language as a complementary and basic language (Bonilla \& Tejada-Sánchez, 2016), is that students tend to perceive English as required and don't understand the relevance of English learning in their career projection (Sánchez, Obando \& Ibarra, 2017).

Taking into account, the present text points out a new approach for the teaching of English as an inner part of courses of psychology that let students achieve higher levels of communicative competence (Serna, 2019; Ceo-Di Francesco, Mora \& Serna Collazos, 2016; Jaime \& Insuasty, 2015) in English across their professional studies as well as more engagement with their under degree education, projecting it at an international level.

In the next sections, it will be explained some core concepts related to this reflection. 


\section{English proficiency of Colombian students}

In Colombia, the National Bilingual Education Program 2004-2019, that was launched by the government during 2004 (Cárdenas \& Miranda, 2014; FandiñoParra, Bermúdez-Jiménez, Lugo-Vásquez, 2012) intended to educate citizens able to communicate themselves in English to insert the country in the global economy and the cultural opening with international standards. One of the goals of this program was that undergraduates could achieve at least a high intermediate level or B2 according to the Common European Framework.

Nevertheless, recent results in English skill tests had shown that Colombian college students had not to get expected scores and the country has been classified with a low English level[1] among with other Latin American nations (Bonilla \& Tejada-Sánchez, 2016; Sánchez, 2013) in the English Proficiency Index (EPI). One evidence was the score of 48,90 points that Colombia got in the EPI in 2017, occupying the place 60 of 88 countries of the World (Education First, 2019).

In the last five years, Colombia's position in English Proficiency Index (EPI) has decreased at least 18 positions in the ranking of countries (for more information see Figure 1).

\begin{tabular}{|c|c|c|c|c|}
\hline 2014 & 2015 & 2016 & 2017 & 2018 \\
\hline 163 & $4{ }^{4}{ }^{5}$ & $=\sum_{172}^{4} 9$ & $\underbrace{}_{/ 80}$ & -76 \\
\hline - Low & - Very low & - Very low & - Low & - Low \\
\hline
\end{tabular}

Figure 1. Colombia proficiency trend during the last five years.

Taken from: https://www.ef.se/epi/regions/latin-america/colombia/

From Latin America, Argentina was the only country in the region that got a high level of English proficiency, followed by Costa Rica, Dominican Republic and Uruguay that got a moderate level of English proficiency and the rest of countries including Colombia had a low level of English proficiency, below Chile and Mexico (for more information see: Table 1). 
Table 1. English Proficiency Index (EPI) 2018 results. Adapted from: https://www.ef.com/ca/epi/

\begin{tabular}{ccc}
\hline Argentina & 27 & \\
Costa Rica & 36 & High \\
Dominican Republic & 37 & Moderate \\
Uruguay & 40 & Moderate \\
Chile & 46 & Moderate \\
Brazil & 53 & Low \\
Guatemala & 55 & Low \\
Panama & 56 & Low \\
Mexico & 57 & Low \\
Peru & 59 & Low \\
Colombia & 60 & Low \\
Bolivia & 61 & Low \\
Ecuador & 65 & Low \\
& & Low \\
\hline
\end{tabular}

The countries with higher levels of proficiency were Sweden (first position), Netherlands (second position), and Singapore (third position). (Education First, 2019).

This information shows to the universities and psychology programs the importance to reinforce English language teaching by using new pedagogical strategies with intensive practical exercises, more class hours in the curriculum, and the students training to present international English tests (Nielsen, 2017).

Currently, English courses in Colombian universities are common to many career curriculums and are separated from professional courses of those programs, but if they want to improve English proficiency of their students, they have to include the use of English across the curriculum courses, because it implies a conceptual articulation between professional and bilingual education. 


\section{Teaching English inside courses of the psychology curriculum}

The curriculum or plan study refers to the set of subjects of a programming career. These courses must have a sequential relation in order of complexity and have an educative purpose. In Colombia, most of the programs have many courses in Spanish and tackle psychological topics in a general and theoretical way, but without a context of practice.

It would be a positive illustrate for the professors, the need to articulate psychological topics, and their enforcement to solve specific problems from local and international contexts too. One strategy to do it's to make a curricular change (Rangel, 2015; Huang \& Garrett, 2015; Williams, McCarley \& Kraft, 2013; McMurray, Roberts, Robertson \& Teoh, 2011) with a teachers' training program in each faculty, to explain them how to make adaptations of contents, academic references and activities into an intercultural approach (Elosúa, 2015) of psychological problems including a local point of view.

This intercultural adaptation has to be gradual, each semester in some courses, beginning with the assignment of tasks in English (Riyaz, 2016). For instance, reading comprehension exercises based on technical readings, then developing lectures, and by requesting students to write essays, to do written reports, and prepare expositions.

The idea's to practice English during class interactions in a natural way and get an advance along with the different curricular levels of the educational program. However, faculty's deans should assess communicative competence in technical English of their students, by the use of standardized tests such as the Graduate Record Examinations Psychology Test (Educational Testing Service, 2017; Kalat \& Matlin, 2000), the AP Psychology Exam (The College Board, 2014) and the Thinking Skills Assessment - TSA (Cambridge Assessment Admissions Testing, 2018).

An additional positive aspect of the use of standardized tests in psychology is the possibility of contrasting the educational quality level of local psychology programs with international psychology programs that apply the same tests. This comparison could be the base to take academic improvement decisions, and for curricular homologation processes between psychology programs (Jessop \& Adams, 2016; Cantu, 2013; Mercer, 2011).

The homologation processes are important to create an international exchange opportunity (Lai, 2018) for Colombian students towards other destinations like European countries, Australia, and the United States and also to increase the academic level of psychology programs in Colombia. 


\section{The importance of communicative and intercultural competences in psychology according to the American Psychological Association}

Contents of psychology curriculum programs are organized mainly by fields, theories, topics, and concepts, but sometimes this theoretical approach is disconnected from social problems of everyday life (Osorio, 2017).

Actually, and based on the previous statement, the American Psychological Association (2018) has a new view of psychologists' profile not as scientists or academics, but as citizens who serve as leaders in their communities, by offering public service, volunteerism, board membership, and other strategic roles to improve community well-being locally, nationally, or globally.

To educate this generation of citizen psychologists, the APA Citizen Psychologist Presidential Work Group proposed a frame of professional competencies to develop along their educative process. Those competencies are 1) the application of psychological knowledge to solving problems in everyday life; 2) community awareness; 3) community engagement; 4) community advocacy; 5) community leadership; and 6) the application of ethical principles and code of conduct (American Psychological Association, 2018).

In addition to, the American Psychological Association Board of Educational Affairs (American Psychological Association, 2013), defined five learning goals for the undergraduate psychology major, which are: Goal 1: Knowledge base in psychology; Goal 2: Scientific inquiry and critical thinking; Goal 3: Ethical and social responsibility in a diverse world; Goal 4: communication; and Goal 5: professional development. Each goal is assessed during under degree levels and during baccalaureate.

The Goal 3, is associated with students' knowledge of formal regulations that govern professional ethics in psychology that contribute to positive outcomes in work settings and in building a society responsive to multicultural and global concerns, and in the particular case of Goal 4, it's divided into three outcomes: demonstrate effective writing for different purposes; exhibit effective presentation skills for different purposes; and interact effectively with others (American Psychological Association, 2013).

Taking into account this educative model of intercultural competences from the American Psychological Association (2018), Colombian programs of psychology could foster in their students the relevance of being bilingual professionals pursuing to understand beliefs and cultural patterns from other countries and also to convey their ideas orally and through different kinds of academic texts. 


\section{Academic international exchange for Colombian psychology students}

Many students travel abroad during one or two semesters of their careers (Lovett, 2018; Lai, 2018), with the main purpose of knowing a different approach to psychology, and this kind of experience is useful for personal growth, but it doesn't have necessarily a direct impact in student's possibility to get access to a master degree or a doctoral program, because, in the majority of cases, students must return to Colombia to finish their under degree program in psychology instead of continuing their studies in the foreign country that they were visiting.

If Colombian psychology programs had homologation processes, students could continue their professional studies in different countries and even begin postgraduate studies. For example, EuroPsy, it's an international academic arrangement among countries which belong to the European Common Framework of Reference and promotes the homologation of under degree studies in psychology (European Federation of Psychologists' Association, 2013; Teichler, 2012) and Colombian programs of psychology could adapt their curricula to this kind of educative model. A homologation process increases the academic quality of psychology programs (Cornejo, 2018) and lets them update them to current pedagogical trends (Pinquart \& Bernardo, 2014).

One way to begin the homologation processes is by the mediation of foreign embassies in Colombia that have scholarships programs, such as Erasmus Mundus from Europe (European Commission, 2019), the Fulbright from the United States (Institute of International Education, 2011), Chevening from The United Kingdom (Foreign and Commonwealth Office, 2018) the Canada-CARICOM Leadership Scholarships (Government of Canada, 2009), and the Australia Awards (Australian Government, 2019).

Also, psychology faculties, could guide their students to know this kind of programs, and counsel them to postulate to those scholarships. If many students are chosen to study postgraduate studies abroad (Bodycott, 2009), it improves the social status of psychology faculties and opens the possibilities to create alliances with particular psychology programs, for collaborative research projects and academic events.

Additionally, an alternative to do it's hiring academic experts in exchange programs from foreign nations (Shor \& Breithaupt, 2016), to advise psychology faculties about how to prepare their students to start post-graduate studies in international destinations. For example, these experts could give academic conferences on topics like cultural characteristics of foreign countries, their lifestyle, job opportunities for non-native students, and the advantages of studying abroad. These conferences give an intercultural approach to students and exemplify them on how to be an autonomous learner and person. 


\section{A proposal of bilingual education within psychology programs in Colombia}

It would be useful for psychology programs to include inside their curriculums, intercultural courses in psychology, pursuing to prepare students to achieve homologation processes of the career in other countries. For example, a course of: specialized academic writing 1: academic essays; specialized academic writing 2: academic reports and papers; communicative competences in advanced English; American and Canadian trends in psychology; European trends in psychology; Australian trends in psychology; African trends in psychology; Asian trends in psychology; and Latin-American trends in psychology.

The idea with these courses is to give students a wider approach of their career in psychology, by studying international trends and current psychosocial problems in different continents. Also these courses could be taught by local professors as well as virtually by foreign professors of psychology from other international colleges as invited teachers.

Some contents that could be taught in these courses are shown in the Table 1.

Table 1. Suggested courses to promote an International scope of psychology in local psychology programs.

\begin{tabular}{|c|c|}
\hline Course & Main topics \\
\hline \multirow{4}{*}{$\begin{array}{l}\text { Specialized academic } \\
\text { writing 1: academic } \\
\text { essays. }\end{array}$} & $\begin{array}{l}\text { 1. Guidelines for writing of specialized essays in } \\
\text { psychology in English. }\end{array}$ \\
\hline & $\begin{array}{l}\text { 2. Writing of essays in the Vancouver citing and } \\
\text { referencing style. }\end{array}$ \\
\hline & $\begin{array}{l}\text { 3. Writing of essays in the Modern Language citing and } \\
\text { referencing style. }\end{array}$ \\
\hline & $\begin{array}{l}\text { 4. Writing of essays in the American Psychological } \\
\text { Association citing and referencing style. }\end{array}$ \\
\hline \multirow{3}{*}{$\begin{array}{l}\text { Specialized academic } \\
\text { writing 2: academic } \\
\text { reports and papers. }\end{array}$} & $\begin{array}{l}\text { 1. Guidelines for writing of specialized reports and } \\
\text { papers in psychology in English. }\end{array}$ \\
\hline & $\begin{array}{l}\text { 2. Writing of reports and papers in the Vancouver citing } \\
\text { and referencing style. }\end{array}$ \\
\hline & $\begin{array}{l}\text { 3. Writing of essays in the American Psychological } \\
\text { Association citing and referencing style. }\end{array}$ \\
\hline
\end{tabular}




\begin{tabular}{|l|ll|}
\hline $\begin{array}{l}\text { Communicative } \\
\text { competences in } \\
\text { advanced English. }\end{array}$ & 1. & $\begin{array}{l}\text { Guidelines for preparing specialized presentations of } \\
\text { psychology in English. }\end{array}$ \\
& 2. & $\begin{array}{l}\text { Guidelines for preparing seminars of psychology in } \\
\text { English. }\end{array}$ \\
\hline $\begin{array}{l}\text { Latin-American } \\
\text { trends in psychology }\end{array}$ & 1. & $\begin{array}{l}\text { Guidelines for preparing academic debates of } \\
\text { psychology in English. }\end{array}$ \\
\hline their ideas.
\end{tabular}

Even similar courses could be adapted from other psychology programs of foreign countries looking for stating connections among scholars, the sharing of teaching experiences, to start common research projects in psychology as well as to create dual degree programs in a virtual methodology which is more accessible and cheaper for students than traveling abroad. 
Many under degree programs of psychology have a local view of the career, but with these courses, their students could open the view of psychology, by listening teachers from other countries, sharing with them ideas and the main professional challenges they may face off. In this way, Colombian students of psychology could understand better social problems in many parts of the World not only in Colombia, and they also could have the possibility to think about studying a virtual master or a virtual doctoral degree program.

In addition to, psychology programs with these dual degree programs could design common scientific journals of psychology in English to publish papers with an international scope of social problems, and it would improve the publication rankings of Colombian psychology programs in comparison with other psychology programs from other Latin American countries such as Mexico or Brazil.

\section{Conclusions}

To sum, Colombian programs of psychology must implement curricular changes (Rangel, 2015; Huang \& Garrett, 2015; McMurray, Roberts, Robertson \& Teoh, 2011) to acquire an international level (Jessop \& Adams, 2016; Van de Vijver, 2013), with better academic quality and new possibilities for their students to travel abroad (Milian, M; Birnbaum, Cardona \& Nicholson, 2015) and find better job opportunities as well.

One strategy to achieve this goal, it's by adapting gradually all academic courses into a bilingual and intercultural approach (Pinquart \& Bernardo, 2014), that let students learn disciplinary and professional topics with a wider perspective of social reality, not only national but also international.

Besides, psychology programs should prepare their students in communicative competences (Serna, 2019; Ceo-Di Francesco, Mora \& Serna Collazos, 2016; Jaime \& Insuasty, 2015) in English to understand the last research advances in scientific literature, to express their ideas inappropriate way and to get excellent results in international tests of psychology.

Finally, Colombian programs of psychology could promote homologation processes with foreign programs of psychology (Cornejo, 2018; Cantu, 2013), to motivate their pupils to study master and doctoral programs in those international programs (Nedelcu \& Ulrich, 2014), to invite international professors to get involved in research projects and to create new common postgraduate programs. 


\section{References}

Ahern, J \& Litt, E. (2018). Creating Buy-In: Integrating IEP Core Curricula and TOEFL Prep. The CATESOL Journal, 30(2), 65-76. Article available at: https://files. eric.ed.gov/fulltext/EJ1206488.pdf

American Psychological Association. (2018). Citizen Psychologist. Preparing the next generation of citizen psychologists: competencies and learning outcomes across levels of education and training. Document available at: https://www.apa.org/about/ governance/citizen-psychologist/citizen-psychologist-curriculum-draft.pdf

American Psychological Association. (2013). APA Guidelines for the Undergraduate Psychology Major version 2.0. Document available at: https://www.apa.org/ed/ precollege/about/psymajor-guidelines.pdf

Australian Government. (2019). Australia Awards Scholarships Policy Handbook. Document available at: https://dfat.gov.au/about-us/publications/Documents/ausawards-scholarships-policy-handbook.pdf

Bodycott, P. (2009). Choosing a higher education study abroad destination. What mainland Chinese parents and students rate as important. Journal of Research in International Education, 8(3), 349-373. ISSN: 1475-2409. Article available at: https://www.researchgate.net/publication/225083776 Choosing a higher education study abroad destination

Bonilla, C \& Tejada-Sánchez, I. (2016). Unanswered questions in Colombia’s language education policy. PROFILE Issues in Teachers' Professional Development, 18(1), 185-201. Article available at: https://revistas.unal.edu.co/index.php/profile/article/ view/51996

Cambridge Assessment Admissions Testing. (2018). Thinking Skills Assessment (TSA) Test Specification. Document available at: https://www.admissionstesting.org/ images/47832-tsa-test-specification.pdf

Cantu, M. (2013). Three Effective Strategies of Internationalization in American Universities. Journal of International Education and Leadership, 3(3), 1-12. ISSN: 2161-7252. Article available at: https://files.eric.ed.gov/fulltext/EJ1136025.pdf

Cárdenas, R.\& Miranda, N. (2014). Implementación del Programa Nacional de Bilingüismo: un balance intermedio. Educación \& Educadores, 17(1), 51-67. Article available at: http://educacionyeducadores.unisabana.edu.co/index.php/eye/article/ view/3045 
Ceo-DiFrancesco, D; Mora, O \& Serna, A. (2016). Developing intercultural communicative competence across the Americas. In S. Jager, M. Kurek \& B. O'Rourke (Eds), New directions in telecollaborative research and practice: selected papers from the second conference on telecollaboration in higher education (pp. 5967). Document available at: https://files.eric.ed.gov/fulltext/ED571343.pdf

Coulson, D \& Homewood, J. (2016). Developing psychological literacy: Is there a role for reflective practice? Journal of University Teaching \& Learning Practice, 13(2). Article available at: https://ro.uow.edu.au/jutlp/vol13/iss2/5/

Cornejo, W. (2018). The teaching of psychology in Colombia: The challenges for the discipline and high quality. International Journal of Psychological Research, 11(1), 6-8. DOI: 10.21500/20112084.3380. Article available at: http://www.scielo.org.co/ pdf/ijpr/v11n1/2011-2084-ijpr-11-01-00006.pdf

Duarte, H. (2016). Desempeño del nivel de inglés en Colombia para el período 20112015. Tesis de grado del Programa de Economía. Cali: Universidad ICESI. Document available in: https://repository.icesi.edu.co/biblioteca digital/ bitstream/10906/81161/1/TG01604.pdf

Education First. (2019). EF EPI. Índice de Dominio del Inglés. Document available: https://www.ef.com.co/_/ / /media/centralefcom/epi/downloads/full-reports/v8/efepi-2018-spanish-latam.pdf

Educational Testing Service. (2017). Graduate Record Examinations Psychology Test Practice Book. Document available at: https://www.ets.org/s/gre/pdf/practice book_psych.pdf

Elosúa, M. (2015). Intercultural competence in the education process. Journal of Education and Learning, 4(1), 72-83. .ISSN 1927-5250. Article available at: https:// files.eric.ed.gov/fulltext/EJ1075168.pdf

European Commission. (2019). Erasmus+ Programme Guide. Document available at: https://ec.europa.eu/programmes/erasmus-plus/resources/documents/erasmusprogramme-guide-2019 en

European Federation of Psychologists' Association. (2013). EuroPsy-the European Certificate in Psychology. EFPA Regulations on EuroPsy and Appendices. Document available: http://www.europsy-efpa.eu/sites/default/files/uploads/EuroPsy\%20 Regulations\%20July\%202013.pdf

Fandiño-Parra, Y; Bermúdez-Jiménez, J \& Lugo-Vásquez, V. (2012). Retos del Programa Nacional de Bilingüismo. Colombia Bilingüe. Educación \& Educadores, 15(3), 363-381. Article available at: http://educacionyeducadores.unisabana.edu. co/index.php/eye/article/view/2172/2951 
Foreign \& Commonwealth Office. (2018). Apply to study in the UK with a Chevening Scholarship. Brochure available at: http://bcckenya.org/assets/documents/ Chevening\%20Scholarships\%202018-19.pdf

Government of Canada, 2009). Canada and the Americas Priorities and Progress. Document available at: http://publications.gc.ca/collections/collection 2009/ maeci-dfait/FR5-41-1-2009E.pdf

Huang, F \& Garrett, M. (2015). A Comparison of Psychology Curriculum and Instruction: China \& America. Universal Journal of Educational Research,3(3), 237242. Article available at: https://files.eric.ed.gov/fulltext/EJ1056097.pdf

Institute of International Education. (2011). Orientation Handbook. A guide for U.S. Fullbright Fellows. Document available at: https://foreign.fulbrightonline.org/ documents/z Orientation Handbook.pdf

Instituto Colombiano para la Evaluación de la Educación. (2018). Guía de Orientación Saber - Pro. Módulos de Competencias Genéricas. Document available at: http:// www2.icfes.gov.co/en/docman/estudiantes-y-padres-de-familia/saber-proestudiantes-y-padres/estructura-general-del-examen/modulos-saber-pro-2017/ modulos-primera-sesion-competencias-genericas-16/5398-guia-de-orientacionmodulos-genericos-saber-pro-2018/file?force-download=1.

Jaime, M \& Insuasty, E. (2015). Analysis of the teaching practices at a Colombian foreign language institute and their effects on students' communicative competence. HOW, 22(1), 45-64. ISSN: 0120-5927. Article available at: https:// www.howjournalcolombia.org/index.php/how/article/view/133

Jessop, N \& Adams, G. (2016). Internationalising the psychology curriculum: Preliminary notes on conception and assessment of anticipated benefits. Psychology Teaching Review, 22(2), 41-52. Article available at: https://www.researchgate. net/publication/316636423 Internationalizing the Psychology Curriculum Preliminary_Notes_on_Conception_and_Assessment_of_Anticipated_Benefits

Kalat, J \& Matlin, M. (2000). The GRE Psychology Test: A Useful But Poorly Understood Test. Teaching of Psychology, 27(1), 24-27. Article available at: https:// www.researchgate.net/publication/247504605 The GRE Psychology Test A Useful but Poorly Understood Test

Lai, L. (2018). Global world, global mind: Narratives of the University of Hong Kong Worldwide Exchange students. Transformation in Higher Education 3(0), 1-18. ISSN: (Online) 2519-5638. Article available at: https://thejournal.org.za/index. php/thejournal/article/view/42/140 
Lovett, T. (2018). Participating in a study abroad program. Concerns and hopes of intending international students. Australian Universities' Review, 60(1), 3-8. Article available at: https://files.eric.ed.gov/fulltext/EJ1169173.pdf

McMurray, I; Roberts, P; Robertson, I \& Teoh, K. (2011). An action research project exploring the psychology curriculum and transitions to employment. Psychology Teaching Review, 17(1), 51-63. Article available at: https://files.eric.ed.gov/fulltext/ EJ932190.pdf

Mercer, J. (2011). Experiencing ERASMUS: Reflections on integrating Polish psychology students onto a year of a degree in the UK. Psychology Teaching Review, 17(1), 13-22. Article available at: https://files.eric.ed.gov/fulltext/EJ932185.pdf

Milian, M; Birnbaum, M; Cardona, B \& Nicholson, B. (2015). Personal and Professional Challenges and Benefits of Studying Abroad. Journal of International Education and Leadership, 5(1), 1-12. ISSN: 2161-7252. Article available at: https://files.eric. ed.gov/fulltext/EJ1135354.pdf

Ministerio de Educación Nacional de Colombia. (2003). Resolución 3461 de 2003. Por la cual se definen las características específicas de calidad para los programas de pregrado en psicología. Document available at: https://www.mineducacion.gov. co/1621/articles-86388_Archivo_pdf.pdf

Mustafa, F \& Anwar, S. (2018). Distinguishing TOEFL score: what is the lowest score considered a TOEFL Score?. Pertanika Journal of Social Sciences \& Humanities, 26(3), 1995-2008. Article available at: https://files.eric.ed.gov/fulltext/ED590428. pdf

Nedelcu, A \& Ulrich, C. (2014). Are we ready for international students? Our university as window and mirror. Procedia - Social and Behavioral Sciences 142, 90 - 96. Article available at: https://www.sciencedirect.com/science/article/pii/ $\underline{\mathrm{S} 1877042814045212}$

Nielsen, J. (2017). Simulacro de las pruebas internacionales: una mirada desde los estándares de lengua. Sophia, 13(1), 55-63. Article available at: http://www.scielo. org.co/pdf/sph/v13n1/v13n1a07.pdf

Nosrati, V. (2015). Reading Test-taking Strategies in General Training IELTS. Advances in Language and Literary Studies, 6(5), 134-141. ISSN: 2203-4714. Article available at: https://files.eric.ed.gov/fulltext/EJ1127466.pdf

Osorio, M. (2017). El currículo: Perspectivas para acercarnos a su comprensión. Zona Próxima, Revista del Instituto de Estudios en Educación y del Instituto de Idiomas Universidad del Norte, 26, 140-151. ISSN 2145-9444. Article available at: http:// www.scielo.org.co/pdf/zop/n26/2145-9444-zop-26-00140.pdf 
Pinquart, M \& Bernardo, A. (2014). Teaching of psychology in countries with advanced versus developing economies. Psychology Teaching Review, 20(1), 26-40. Article available at: https://files.eric.ed.gov/fulltext/EJ1149740.pdf

Rangel, H. (2015). Una mirada internacional de la construcción curricular. Por un currículo vivo, democrático y deliverativo. Revista Electrónica de Investigación Educativa, 17(1), 1-16. Article available at: http://www.redalyc.org/articulo. oa?id=15532949001

Riyaz, S. (2016). Importance of English communication skills. International Journal of Applied Research, 2(3), 478-480. ISSN: 2394-5869. Article available at: http://www. allresearchjournal.com/archives/2016/vol2issue3/PartH/2-3-47.pdf

Sabet, M \& Reza, H. (2017). On the relationship between the IELTS listening and listening in Academic English Programs. Advances in Language and Literary Studies, 8(2), 170-179. ISSN: 2203-4714. Article available at: https://files.eric. ed.gov/fulltext/EJ1144049.pdf

Sánchez, A; Obando, G \& Ibarra, D. (2017). Learners' perceptions and undergraduate foreign language courses at a Colombian public university. HOW, 24(1), 63-82. http://dx.doi. org/10.19183/how.24.1.310. Article available at: http://www.scielo. org.co/pdf/how/v24n1/v24n1a04.pdf

Sánchez, A. (2013). Documentos de trabajo sobre Economía Regional \# 191. Bilingüismo en Colombia. Colombia: Banco de La República. ISSN: 1692-3715. Document available at: http://www.banrep.gov.co/docum/Lectura finanzas/pdf/dtser 191.pdf

Serna, H. (2019). Implementing an instructional design on intercultural communicative competence (ICC) with foreign language students aimed at joining the corporate world. English Language Teaching, 12(3), 161-177, E-ISSN 1916-4750. Article available at: https://www.researchgate.net/publication/331046601 Implementing an Instructional Design on Intercultural Communicative Competence ICC With_Foreign_Language_Students_Aimed_at_Joining_the_Corporate_World

Shor, R \& Breithaupt, L. (2016). Teaching Abroad as Graduate Students: Reflections on an Applied Cross Cultural Psychology Course in Morocco. International Psychology Bulletin, 20(4), 43-46. Article available at: https://www.researchgate. net/publication/312167643 Teaching_International Psychology Teaching Abroad as Graduate Students Reflections on an Applied Cross Cultural Psychology Course in Morocco

Taylor, J \& Hulme, J. (2015). Introducing a compendium of psychological literacy case studies: Reflections on psychological literacy in practice. Psychology Teaching Review, 21(2), 25-34. Article available at: https://files.eric.ed.gov/fulltext/ EJ1146628.pdf 
Teichler, U. (2012). International Student Mobility in Europe in the Context of the Bologna Process. Journal of International Education and Leadership, 2(1), 1-13. ISSN:2161-7252. Article available at: https://www.researchgate.net/ publication/281812747 International Mobility in Europe in the Context of the Bologna Process

The College Board. (2014). Psychology Course Description. Document available at: https://secure-media.collegeboard.org/apc/ap-psychology-course-description.pdf

Van de Vijver, F. (2013). Contributions of Internationalization to Psychology: Toward a Global and Inclusive Discipline. American Psychologist, 68, 761-770. DOI: 10.1037/a0033762. Article available at: https://www.researchgate.net/ publication/259251149 Contributions of Internationalization to Psychology Toward_a_Global_and_Inclusive_Discipline

Williams, J; McCarley, N \& Kraft, J. (2013). History and systems of psychology: A course to unite a core curriculum. College Quarterly, 16(2). Article available at: http://collegequarterly.ca/2013-vol16-num02-spring/williams.html

\section{Authors}

${ }^{*}$ Germán Andrés Torres-Escobar Is a full-time professor at Universidad Católica Luis Amigó, Faculty of Psychology and Social Sciences in Bogotá. His research interests are schooling topics, educational psychology, and school guidance. He also worked as school counselor in two private educational institutions

ORCID: https://orcid.org/0000-0001-6417-8850

Rolan Arcadio Correa Lopez Is a full-time professor at Universidad Católica Luis Amigó, Faculty of Psychology and Social Sciences in Bogotá. His research interests are neuropsychology, neurosciences and cognitive processes in human beings. He also teaches psychology at Universidad Cooperativa de Colombia.

ORCID: https://orcid.org/0000-0002-5345-6875

How to reference this article: Torres-Escobar, G. A., \& Correa-López, R. A. (2020). Promoting an Academic International Profile in Undergraduate Students of Psychology Programs in Colombia. GIST - Education and Learning Research Journal, 21, 225-242. https://doi. org/10.26817/16925777.775 